\title{
THE CULTURAL COMMENTARY METHOD IN STUDY OF A COMPOSER'S CREATIVE BIOGRAPHY (BY THE EXAMPLE OF M. GLINKA'S MEMOIRS HERITAGE)
}

\author{
Kateryna Pavelko \\ Ukraine, Kyiv, Tchaikovsky National Music Academy of Ukraine, \\ Department of Theory and History of Culture, \\ postgraduate student
}

DOI: https://doi.org/10.31435/rsglobal_ws/30062019/6565

\section{ARTICLE INFO}

Received: 20 April 2019

Accepted: 14 June 2019

Published: 30 June 2019

\section{KEYWORDS}

Cultural commentary, daily life,

creative biography, memoirs, musical art, M. I. Glinka.

\begin{abstract}
The history of formation of the cultural commentary principle, an effective scientific method used in study of various texts, is discussed in the article. The current experience in its use in literary criticism, musicology and musical culturology is analyzed herein. The own definition of this method is offered. Prospects for this methodological tool in researches of the composers' creative biographies are specified by the example of studying the memoir heritage of M. Glinka. Referring to the cultural commentary while studying M. Glinka's memoirs involves many different sources for proper understanding of the described details of the composer's life, which at first sight are not related to his creative activity. This approach helps expand the selection of facts for commenting and include information, earlier left beyond vision of musicologists and culturologists. Commenting on the outstanding composers' memoirs is a peculiar way of knowing the musicians' personality, an opportunity to dive deeper into the past, to find meanings hidden under the surface of the text.
\end{abstract}

Citation: Kateryna Pavelko. (2019) The Cultural Commentary Method in Study of a Composer's Creative Biography (by the Example of m. Glinka's Memoirs Heritage). World Science. 6(46), Vol.2. doi: 10.31435/rsglobal_ws/30062019/6565

Copyright: (C) 2019 Kateryna Pavelko. This is an open-access article distributed under the terms of the Creative Commons Attribution License (CC BY). The use, distribution or reproduction in other forums is permitted, provided the original author(s) or licensor are credited and that the original publication in this journal is cited, in accordance with accepted academic practice. No use, distribution or reproduction is permitted which does not comply with these terms.

Introduction. Daily life seems to be one of the most important and studied issues in different modern researches. A person's routine life, his surrounding and living conditions often happen to be in the limelight. Growing interest in daily life is undeniably justified. After all, no matter what activity we study, the influence of everyday life is obvious and even primary in some cases.

Due to the increasing attention to daily life, the focus of biographical researches has shifted. «The private life, the art of life, everyday life seem attractive to contemporary historians», - said B. V. Markov, culture expert and philosopher, author of the textbook «The culture of everyday life» [5, p. 17].

A tendency to explore the composers' everyday life is currently observed in the music culturology and musicology. In this sense, researches of the musicians' creative biographies considering a complicated creative process as coupled to everyday life seem to be promising and effective. Tyshko S., known musicologist and culture expert, made a neat observation in the article «Issues of studying the creative biography in contemporary musicology» stating that «any life is always wider then counterpoint and orchestration lessons, but sometimes incredibly responsive in one or the other» $[8$, p. 220].

Exploring everyday life, personal materials (diaries, memoirs, letters) and era documents (sources associated with the studied period) are believed to be particularly important. At the same time, just to know certain facts from literature is not enough to understand and reconstruct the 
everyday life of the time and its meaning in the musicians' life. Available sources should be objectively rendered. The study of the past typically is time-consuming and problematic due to remoteness of the studied object. Many events and actions happened several centuries ago may lose the original meaning in the contemporary understanding, acquire new meaning, untypical for the time, or remain unclear at all. That is why thorough and thoughtful reading of the studied texts, their explanation and proper interpretation are believed to be very important. The method of cultural commentary contributes to resolving the mentioned problems (in literary criticism, this method was successfully used, for example, by V. Nabokov and Yu. Lotman, in musicology and music culturology this comment was first developed by S. Tyshko in collaboration with S. Mamayev and G. Kukol).

The purpose of the article is to study the history of formation of the cultural commentary principle and the available experience in its application, to offer own definition of the method by the example of the studied memoirs of M. Glinka, to specify prospects for the methodological tools in researches of the composers' creative biographies.

Thus, particularities of the commentary were first developed in textual criticism, formulated and clearly stipulated by literary critic and bibliographer S. A. Reyser in «Paleography and textual criticism of the New time» [7]. The researcher noted that the comments have a long history: «When in old times, a copyist did not understand something in the work, he either missed an unclear spot, or made a fair copy, or corrected the manuscript according to his understanding, and sometimes, being proud of own "erudition" and for the progeny's edification, put down marginal notes of the difficult word or fragment» [7, p. 289]. Gradually, the comment tools grew and over time lost their original explanatory function. M. Gasparov, known literary critic, philologist and translator, remarked: «New forms were developed for comments. A hundred years ago, comments were intended for readers with a vague general idea of ancient history and culture, and they needed just to recollect some halfforgotten details. Readers today, on the contrary, usually know details $\langle\ldots\rangle$, but not the general system. Therefore, the main thing in modern commentary is not the line-by-line notes to certain names, but the general preamble about the work itself and about the culture it belongs to» [2, p. 272].

Currently in textual criticism, there are several types of commentary, each is intended for solving certain problems and contains information corresponding to its purpose. Reyser S. indicates the following:

- bibliographic or historiographic commentary containing, as a rule, general information about the commented text (information about the manuscript, time and place of publication, differences of print versions, its structure, etc.);

- historical and literary commentary revealing to readers the meaning of the work, the author's concept, features of the creative process, the ideological content, hermeneutical options;

- real commentary aimed at restoring the lost original meaning of words, expressions, actions of characters, etc. ${ }^{1}$

In spite of obvious differences in the comments shown by S. Reyser, the researcher at the same time highlights one feature typical for all its types of this genre: «<...>Regardless of a category of readers of the comment, the latter is not apart from the text, but subordinated to it - it should help the reader understand the text» [7, p. 293]. In this context, Gasparov's observation in his book «Notes and extracts» seems right: «I feel dumb and unnecessary in front of a text (and a man), but understanding and participating in front of the text with a commentary (and the conversation between two men) [2, p. 219].

It should be noted that the above features of the commentary genre clarify the specifics of its application. However, the cultural commentary principle we are interested in is not specifically defined by S. Reyser. Looking ahead, it was not found in other works, describing cultural commenting experience (we say about monumental works by Yu. Lotman and V. Nabokov below discussed in details). Because the precise definition is certainly required for the correct use, we would like to present our interpretation of this definition:

Cultural commentary is a certain method to study and comprehend the text, implying its consideration in broader cultural and historical context, a thorough analysis and overall study of the information contained in the source, restoration of the lost meaning of facts, events, actions directly or indirectly mentioned in the commented work.

It should be noted that cultural commentary is not intended to contain complete information. Just like any other type of comments, it is meant to supplement the text and to clarify the meaning. S. Reyser stated: «The commentary is not unchangeable, standard and stipulated once and for all. Each epoch, perhaps even every generation needs different comments» [7, p. 305]. This method of

\footnotetext{
${ }^{1}$ For more details about the commentary genre features in the textual criticism, see [7, p. 295 - 320].
} 
researching allows readers a deeper insight of the text, makes them wonder and, maybe, start an imagined dialogue with the author and the commentator.

S. Reyser's statement that the commentary is entirely dependent on the commented text and not considered as an independent genre [7, p. 293] is mentioned by Yu. Lotman in his famous work «The novel by Pushkin "Eugene Onegin". Comments» [4], a classic example of the use of cultural commentary in the literary criticism. Within the context of his work, the researcher interpreted this point in two ways. First, Yu. Lotman notes that the comment suggests a parallel research over the novel. Second, acquaintance with his commentary on «Eugene Onegin» should be inextricably linked to the reading of Pushkin's text. [4, p. 473]. It should be noted that this point is peculiarly rendered in the researching of the musician's creative biography. This is primarily because that commenting on the composers' memoirs and letters implies synchronous learning not only written, but also musical heritage. Facts and information contained in the composers' memoirs substantially lose their meaning when considered separately, out of the context of their musical creativity. And on the contrary, only upon stories of compositions, possible incentives to and influence on their creation become known in details, the available information in memoirs of the author and his contemporaries is carefully examined, the figurative and emotional content of the works is fully clarified.

Also the well-known example of the cultural commentary method in the literary criticism is work by V. Nabokov - «Commentary to the novel by A. S. Pushkin "Eugene Onegin"» [6]. Despite the similar research interests of Yu. Lotman and V. Nabokov (choosing the same work by A. Pushkin, and the commentary as the main method to study and present the material), their works show different approaches and views on the research. Unlike the laconic and restrained commentary by Yu. Lotman, Nabokov's observations are detailed, often reflecting his subjective impressions, sometimes autobiographical. The information saturation of Nabokov's comments should be noted as well. His work contains valuable information and observations testifying to the long-term research on the novel by A. Pushkin and the diligent collection of materials.

Currently in musicology and musical culturology, the works by S. Tyshko, including collaborated with S. Mamayev and G. Kukol, ${ }^{1}$ seem to be a good and convincing example of cultural commentary. The authors of the method note that the techniques applied in the «school of cultural commentary» in literary criticism (in this case they are based on experience described in the works by Yu. Lotman and V. Nabokov) seem also appropriate in researches of musical culture and art $[11$, p. 8]. In the books devoted to Mikhail Glinka's travels to Ukraine, Germany, Spain and the Caucasus [11;12; 10; 9], the authors studied in detail the era of the composer's life and offered a new understanding of many facts of his creative life history. According to them, the main task for researchers is «to introduce the accumulated historical and musicological material (memoirs, comments, etc...) into a wider cultural and historical context, pairing the text of "Memoirs" and comments to the specific era realities: the data of related disciplines: art, literature, local history, topography, ethnography, genealogy etc.» [11, p. 3].

Now let's pass right to the features of the cultural commentary method in the musical art and musical culturology. Based on the experience described in the works by S. Tyshko in collaboration with S. Mamayev and G. Kukol, by the example of Mikhail Glinka's memoirs, we would like to consider prospects for the use of this methodological principle in the study of famous musicians' creative biographies.

Results of the research. The biography of the outstanding composer Mikhail Glinka (1804 1857) is a bright and clear example of the close relationship of everyday life and creative work. Emotionality, sensitivity, high susceptibility to reality and life conditions are features characterizing the composer's creative personality. The composer's memoirs show importance of his daily life. His autobiography («Memoirs» [3]) is full of descriptions of different everyday moments in his life. Details, seeming insignificant at first glance, run through Glinka's memoirs, intertwined with descriptions of stories about works and sometimes become their part.

Thus, culturological commenting on Glinka's memoirs involves many different sources for proper understanding of the described details of the composer's life, which at first sight are not directly related to his creative activity. This approach helps expand the selection of facts for commenting, and include information, earlier left beyond vision of musicologists and culturologists. Thus, some isolation peculiar to works within one scientific discipline is overcome. «Even in such a limited area as the study of art creativity, it is hard for art historians to understand musicologists, for literary critics - art theorists, etc. Facts, long-known to ones, remain out of view of others», - noted S. Tyshko and S. Mamayev in the book «Wanderings of Glinka. Ukraine» [11, p. 4].

${ }^{1}$ See: $[8 ; 11 ; 12 ; 10 ; 9]$. 
Furthermore, the commentation is believed to be an effective technique in the reconstruction of the historical and cultural pattern and features of daily life of that period. The cultural commentary not just explains certain fragments in the composer's memoirs, but opens its borders, compares it to a variety of sources. Philosopher and culture expert V. S. Bibler pointed that to understand the text was possible only in the context of other documents of the epoch [1, p. 33]. The inclusion of «Memoirs» into the documentary context of Glinka's time provides a more holistic view of the composer's period, enlivens the cultural background of his life. The task of the commentary, in this case, through particulars and sometimes line-by-line notes to certain names or events is to create an overall picture and understanding of the cultural and everyday environment in which the composer lived and created his works.

The commentary method allows to resolve another complexity in studying Glinka's creative biography. The composer wrote his memoirs and letters over a century and half ago, so reading them today we often misunderstood many phenomena of Glinka's life. In this context, the following situation, described in the composer's «Memoirs», seems to be very demonstrative - Glinka mentioned in his notes friendly gatherings in his Warsaw apartment, drinking punch and wine to «warm the stomach», and all this against the raging cholera epidemic [3, p. 205]. For the modern reader the meaning of this action can be confusing and surprising. However, as we found out, in the era of Mikhail Glinka, wine was often used as a preventive measure, because assumingly helped fight cholera. And in the light of new facts, the composer's pastime seems to be quite reasonable. Certain facts, statements, events, etc., which have lost a typical meaning over time, are explained by comments. It is appropriate to quote from S. Reyser's remark, who, justifying the need for text commenting, also drew attention to this feature of reading the works of the past: «Do not forget that each era always reads old seemingly clear works with new historical and aesthetic positions. Although the text is unchanged, its life in a certain sense continues after its creation and publication. The contemporaries perceive the text in one context, but the experienced descendants - in different one» [7, p. 296].

S. Tyshko and S. Mamayev note that the commentary principle helps «clearing» the creative portrait of Mikhail Glinka from traditional misconceptions due to misunderstanding of many facts, allows avoiding errors and prejudices of previous studies while studying the composer's memoirs [11, p. 6]. The cultural commentary presupposes an objective reading of the information, thus facts and events are important in their own context, not the interpretations and reflections. S. Tyshko and S. Mamayev note: «The traditional restrictions prevailed over the former commentator should be overcome to comment any text in new way, thus not forgetting that each new era, breaking the previous misconception, brings its own mistakes and prejudices» $[11, \mathrm{p} .6]$.

Another important observation of the researchers of Glinka's travels should be noted as well. In their book, devoted to the years spent by the composer in Spain [10], S. Tyshko and G. Kukol share an important opinion that the commentary is «the only means to "get feeling" the character's image and the surrounding realities» $[10$, p. 5]. And this statement is true regarding Glinka's memoirs. Almost all previous researchers of the composer's creative biography while studying his «Memoirs» usually paid attention at the most significant facts and events and the names of famous artists and left behind details of everyday life and leisure, health complaints, as well as the personalities of the people not known for history, but special for Glinka. And it is important that the composer created his «Memoirs» assuming them to be published ${ }^{1}$. All information therein was obviously intended for readers and meant to somehow reveal the way of the musician's life, his character traits and specifics of his creative process. Everything that was important and significant for Glinka, definitely, should be important for the researcher of his creative biography. S. Tyshko and G. Kukol noted: "After all, we can only assume what in Glinka's memoirs was the plot, and what its true trigger. Actually we have only what Glinka wanted to show us, and we create ourselves all the rest - that is the actual plot. Thus, we have to remember for Glinka!» [10, p. 5].

Let's consider another example, when a thorough analysis and commentary on Glinka's memoirs help restore the meaning lost over time of the composer's comments in the autobiography. Thus, in «Memoirs» related to the period when Mikhail Glinka lived in Warsaw in the mid-nineteenth century, the composer mentioned several times his regular visits to the suburban restaurant of Mr. Ohm and that he liked to be there [3, p. 209-210]. For the modern reader at first glance, this statement means nothing special, seems simple and clear, and unworthy of particular interest in the context of Glinka's creativity. However, a closer look at the information in the memoirs, search for

${ }^{1}$ For more details, see: [11, p. 7]. 
more information on this subject allowed to determine the original meaning of the composer's comments, and to reveal new facts of his creative biography.

We found information on the owner of the restaurant mentioned by Glinka in the electronic personal database developed by Rainer Berg, scientist [13]. We found that there was a grave at the Warsaw Evangelical-Augsburg cemetery of Rudolf Ohm, a well-known restaurateur of the nineteenth century, who also owned a large garden in the suburbs of Warsaw [13]. Specified in the database years of his life (1796 - 1857) and his activities allow with full confidence to state that it was the man mentioned by M. Glinka in his «Memoirs». On his land, R. Ohm arranged the garden, a cafe with summerhouses and a winter dining pavilion. However, R. Ohm's place became popular among Warsaw elite, above all, thanks to orchestral concerts and solo performances of Polish and foreign artists. R. Ohm's musical events attracted audience from Warsaw.

New information greatly expanded, and even changed the idea of this place, comparing to the one while reading the composer's «Memoirs», and discovered its place in the cultural life of Warsaw of that period. The restaurant mentioned in «Memoirs» was not just a café, but a kind of place for musical elite of the city to gather in. At R. Ohm's, Glinka could meet almost all the musical figures in Warsaw. Glinka was known to meet famous Polish composer K. Kurpinsky at that place, and they had «conversations about the art» [3, p. 210]. Besides, Glinka's «Memoirs» showed that frequent visits to $\mathrm{R}$. Ohm contributed to his creative activity. During these visits, the composer wrote three romances, including romance «Rozmowa» (Conversation), lyrics by Adam Mickiewicz, devoted to inspiring Emilia Ohm, the restaurant owner's daughter [3, p. 209]. The commentary on the fragment from Glinka's memoirs allows to clarify the true meaning of the composer's frequent visits to R. Ohm's restaurant, to find reasons of dedication of the work composed in that period and the addressee's personality. This knowledge, in turn, assumes to reconsider some known interpretations of romance «Rozmowa», opens up new possibilities for understanding and execution of the composition.

Conclusions. Thus, and so, we see that the reference to the culturological commenting on Glinka's «Memoirs» and letters is just inevitable while studying his everyday life, revealing its possible effects and incentives for the composer's creativity. This method of study provides the most productive result when working with the text containing many names and facts, the text, created over a century and half ago, and therefore not oriented towards readers of the $21^{\text {st }}$ century.

By way of conclusion, we note that the commentary on the memoirs heritage of outstanding composers is a peculiar way of knowing the musicians' personality, an opportunity to dive deeper into the past, to find meanings hidden under the surface of the text. And sometimes in searching for answers, explanations and additions often left out of one study, the commentary becomes the only possible way to study the text.

\section{REFERENCES}

1. Библер В. С. Диалог. Сознание. Культура (идея культуры в работах М. М. Бахтина) // Одиссей. Человек в истории. Исследования по социальной истории и истории культуры. - М., 1989. - С.21 - 59.

2. Гаспаров М. Л. Записи и выписки. - М.: Новое литературное обозрение, 2001. - 416 с.

3. Глинка М. Записки / под ред. В. Богданова-Березовского. Вступ. статья В. Богданова-Березовского, комм. А. Орловой. - Л.: Госмузиздат, 1953. - 283 с.

4. Лотман Ю. М. Роман А. С. Пушкина «Евгений Онегин». Комментарий: пособие для учителя // Лотман Ю. М. Пушкин: Биография писателя; Статьи и заметки, 1960 - 1990; «Евгений Онегин»: Комментарий. - СПб.: Искусство-СПБ, 1995. - С. 472 - 762.

5. Марков Б. Культура повседневности: учебное пособие. - СПб.: Питер, 2008. - 352 с.

6. Набоков В. Комментарий к роману А. С. Пушкина «Евгений Онегин». - СПб.: Искусство - СПб, Набоковский фонд, 1998. - 928 с.

7. Рейсер С. А. Палеография и текстология Нового времени. - М.: Просвещение, 1970. - 336 с.

8. Тышко С. В. Проблемы изучения творческой биографии в современном музыкознании // Науковий вісник Національної музичної академії України. - К., 2009. - Вип. 80. - С. 207 - 221.

9. Тышко С. В. Странствия Глинки. Комментарий к «Запискам». - Ч. IV: Кавказ. - К.: ЛАТ\&К, 2015. - 244 с.

10. Тышко С., Куколь Г. Странствия Глинки. Комментарий к «Запискам». - Ч. III: Путешествие на Пиренеи, или Испанские арабески. - К.: Клякса, 2011. - 542 с.

11. Тышко С., Мамаев С. Странствия Глинки. Комментарий к «Запискам». - Ч. 1: Украина. - К.: Радуга, 2005. - 214 c.

12. Тышко С., Мамаев С. Странствия Глинки. Комментарий к «Запискам. - Ч. II: Глинка в Германии, или Апология романтического сознания. - К.: Задруга, 2002. - 509 с.

13. Ohm, Rudolf [electronic resource] - Access mode: http://www.baza-nazwisk.de/suche.html?data=60116 